\title{
Low-Affinity Blockade of Neuronal N-Type Ca Channels by the Spider Toxin $\omega$-Agatoxin-IVA
}

\author{
Serguei S. Sidach and Isabelle M. Mintz \\ Department of Pharmacology and Experimental Therapeutics, Boston University Medical Center, Boston, Massachusetts \\ 02118
}

\begin{abstract}
The recognition of neuronal $\mathrm{Ca}$ channel diversity has led to considerable efforts to identify useful classification criteria. Here, we revisit the pharmacological definition of $\mathrm{P}$ - and Q-type $\mathrm{Ca}$ channels, which is based on their respective high and low sensitivity to the spider $\omega$-agatoxin-IVA ( $\omega$-Aga-IVA), using whole-cell recordings of the Ca channel currents carried by $5 \mathrm{~mm} \mathrm{Ba}^{2+}$ in isolated rat subthalamic and sympathetic neurons. In subthalamic neurons, $\omega$-Aga-IVA ( $1 \mu \mathrm{M})$ targeted multiple Ca channels. One population was blocked with high potency. These channels carried $50.4 \pm 3.4 \%(n=5)$ of the control current and showed the same inactivation kinetics and voltage-dependent high affinity for $\omega$-Aga-IVA as do prototypic P-type Ca channels. Other $\mathrm{Ca}$ channels were targeted with weaker potency. This heterogeneous population contributed to $14.0 \pm 1.7 \%(n=5)$ of the control current. It included $\mathrm{N}$-type $\mathrm{Ca}$ channels as well as highthreshold $\mathrm{Ca}$ channels that displayed the pharmacological sig-
\end{abstract}

nature of Q-type Ca channels but resembled P-type Ca channels in their gating properties. $\mathrm{N}$-type Ca current block by $\omega$-Aga-IVA $(1 \mu \mathrm{M})$ was further investigated in sympathetic neurons, which mainly express this $\mathrm{Ca}$ channel type. Block was incomplete ( $\sim 30 \%$ of the control current). Its relief at positive potentials was consistent with $\omega$-Aga-IVA acting as a channel-gating modifier. These effects did not reflect a complete loss of selectivity, because $\omega$-Aga-IVA ( $1 \mu \mathrm{M})$ had no effect on subthalamic $\mathrm{Na}$ and $\mathrm{K}$ currents or their T- and L-type Ca currents. Our data confirm that $\omega$-Aga-IVA is a selective P-type Ca channel blocker. However, its diminished selectivity in the micromolar range limits its usefulness for functional studies of Q-type Ca channels.

Key words: spider toxin; $\omega$-agatoxin; subthalamic neuron; sympathetic neuron; Purkinje neuron; N-type Ca channel; Q-type Ca channel; P-type Ca channel
Venoms of invertebrate and lower vertebrate species are rich in toxins designed to produce rapid immobilization of their victims (Olivera et al., 1985). Although mammals are rarely the targeted prey, many venom toxins are surprisingly potent blockers of ion channels found in mammalian CNS, and those with the greatest selectivity are now widely used (Catterall, 1980; Rehm and Tempel, 1991; Adams et al., 1993).

Venom toxins are specially useful for studies of high-threshold voltage-gated $\mathrm{Ca}$ channels whose identification mainly depends on pharmacological criteria (McCleskey et al., 1987; Llinas et al., 1989; Mintz et al., 1992; Sather et al., 1993; Newcomb et al., 1998). In mammalian central neurons, high-threshold L-, N-, and P-type $\mathrm{Ca}$ channels share the same electrophysiological signature at the single channel (Plummer et al., 1989; Usowicz et al., 1992; Elmslie, 1997; Dove et al., 1998) and macroscopic levels (Regan et al., 1991; Lorenzon and Foehring, 1995). Still, they can be distinguished by their respective sensitivity to dihydropyridines (DHPs) (Nowycky et al., 1985; Fox et al., 1987; Cox and Dunlap, 1992), the snail toxin $\omega$-conotoxin GVIA ( $\omega$-CgTX) (Cox and Dunlap, 1992; Boland et al., 1994), and the spider toxin $\omega$-Agatoxin-IVA ( $\omega$-Aga-IVA) (Mintz et al., 1992; Brown et al., 1994).

Pharmacological studies in expression systems have confirmed that DHPs, $\omega$-CgTX, and $\omega$-Aga-IVA target distinct Ca channels (Dunlap et al., 1995; Tsien et al., 1995). The match between structural identity and pharmacology is now well established for Land $\mathrm{N}$-type $\mathrm{Ca}$ channels. Class $\mathrm{C}$ and $\mathrm{D}$ genes encode the $\alpha 1$ subunit ( $\alpha 1 \mathrm{C}$ and $\alpha 1 \mathrm{D})$ of the dihydropyridine-sensitive L-type $\mathrm{Ca}$ channels (Mikami et al., 1989; Williams et al., 1992b), whereas class $\mathrm{B}$ (or BIII) genes encode that $(\alpha 1 \mathrm{~B})$ of the $\omega$-CgTX-sensitive N-type Ca channels (Williams et al., 1992a; Fujita et al., 1993).

Received Feb. 7, 2000; revised July 5, 2000; accepted July 14, 2000.

This work was supported by National Institutes of Health Grant NS-34550 to I.M.M. We thank Dr. Bruce P. Bean for helpful comments.

Correspondence should be addressed to Isabelle M. Mintz, Department of Pharmacology and Experimental Therapeutics, Boston University Medical Center, 80 East Concord Street, Boston, MA 02115. E-mail: imintz@bu.edu.

Copyright (C) 2000 Society for Neuroscience $0270-6474 / 00 / 207174-09 \$ 15.00 / 0$
However, the diversity of $\omega$-Aga-IVA-sensitive $\mathrm{Ca}$ channel currents seen in mammalian neurons has made it difficult to establish the precise relationship between the class A gene products and their native counterparts. Both $\mathrm{P}$-type $\mathrm{Ca}$ channels, which are potently blocked by the toxin $\left(K_{\mathrm{d}}, \sim 1 \mathrm{nM}\right)$ (Mintz et al., 1992), and Q-type Ca channels, which show weaker sensitivity to the toxin (Randall and Tsien, 1995), have been related to the $\alpha 1 \mathrm{~A}$ gene family (Mori et al., 1991; Sather et al., 1993; Niidome et al., 1994; Berrow et al., 1996). Recent findings reconcile these conflicting reports by suggesting that $\mathrm{P}$ - and Q-type $\mathrm{Ca}$ channels are homologous. Their distinct phenotypes may reflect the differential splicing of the $\alpha 1 \mathrm{~A}$ subunit (Bourinet et al., 1999) or its association with different $\beta$ subunits (Stea et al., 1994; Moreno et al., 1997; Mermelstein et al., 1999).

The prototypic P- and Q-type Ca channel currents have been described in cerebellar Purkinje neurons (Regan, 1991; Usowicz et al., 1992) and in cultured cerebellar granule cells (Forti et al., 1994; Randall and Tsien, 1995; Tottene et al., 1996). Because differences in toxin sensitivity are often difficult to quantify experimentally (measures of the steady-state current block by low toxin concentrations may be confounded by current rundown, toxin nonspecific binding and, in brain slice studies, poor access to the tissue), subtle differences in gating have been used as a criterion to differentiate these two channel populations. In cerebellar granule cells, Q-type $\mathrm{Ca}$ currents are distinguished from the P-type $\mathrm{Ca}$ currents by their fast inactivation kinetics (Randall and Tsien, 1995).

To further characterize the $\omega$-Aga-IVA-sensitive Ca channels, we have recorded voltage-gated $\mathrm{Ca}$ channel currents in freshly isolated rat subthalamic neurons. These neurons constitute a homogeneous population of extrinsic glutamatergic neurons (Iribe et al., 1999), with little or no contamination from interneurons (Hammond and Yelnik, 1983). They are robust and easily dissected from brain slices. In addition, they display a complex repertoire of voltage-gated $\mathrm{Ca}$ channels, all of which made them well suited for this study. Recently, they have attracted special attention after reports that their hyperactivity contributes to the symptoms of Parkinson's disease (Bergman et al., 1990). 
We found that nanomolar concentrations (50-100 nM) of the toxin $\omega$-Aga-IVA target subthalamic $\mathrm{Ca}$ channels that are remarkably similar to P-type $\mathrm{Ca}$ channels in cerebellar Purkinje and granule neurons (Tottene et al., 1996). In contrast, high toxin concentrations affect a heterogeneous channel population: $\omega$-AgaIVA $(1 \mu \mathrm{M})$ blocked $\omega$-CgTX-sensitive N-type Ca channels and high-threshold $\mathrm{Ca}$ channels that display some but not all the characteristics of cerebellar granule cell Q-type Ca channels.

\section{MATERIALS AND METHODS}

Enzymatic dissociation of subthalamic, Purkinje, and sympathetic neurons. Subthalamic neurons were freshly dissociated with enzyme (Mintz et al., 1992). Briefly, 400- $\mu \mathrm{m}$-thick coronal slices were cut, in ice-cold Ringer's solution, from brains of 9- to 13-d-old rats. The subthalamic nucleus was immediately dissected out under $400 \times$ magnification. It was then incubated for $7 \mathrm{~min}$ in a solution maintained at $35-36^{\circ} \mathrm{C}$, which contained (in mM): $81.4 \mathrm{Na}_{2} \mathrm{SO}_{4}, 30 \mathrm{~K}_{2} \mathrm{SO}_{4}, 5.8 \mathrm{MgCl}_{2}, 10 \mathrm{Na}$-HEPES, 20.4 glucose, and $0.5 \%$ phenol red, pH 7.4 with $\mathrm{NaOH}$, plus $3 \mathrm{mg} / \mathrm{ml}$ protease type XXIII. All chemicals were purchased from Sigma (St. Louis, MO) unless mentioned otherwise. After the incubation with enzyme, the brain tissue was rinsed in a minimum essential medium (MEM) solution (Life Technologies, Grand Island, NY; reference 11090-073) which contained Earle's salts with $10 \mathrm{~mm}$ Na-HEPES, $15 \mathrm{~mm}$ glucose, $1 \mathrm{mg} / \mathrm{ml}$ bovine serum albumin, and $1 \mathrm{mg} / \mathrm{ml}$ trypsin inhibitor $\left(36^{\circ} \mathrm{C}, \mathrm{pH} 7.4\right.$ with $\left.\mathrm{NaOH}\right)$. The Earle's salt solution had no glutamine. Cells were dissociated in the same MEM solution by gentle trituration through a fire-polished glass pipette. This protocol yields a homogeneous population of neurons that retain enough of their primary dendrites for the typical morphology of subthalamic neurons to be recognized (Hammond and Yelnick, 1983).

Purkinje neurons were isolated form the cerebellar vermis of 9- to 11-d-old rats. The cerebellum was dissected out in ice-cold Ringer's solution. The vermis was divided into three or four pieces $\left(\sim 1 \mathrm{~mm}^{3}\right)$, which were incubated for $8 \mathrm{~min}$ in the enzyme-containing solution described above. The subsequent steps in the procedure were then identical to those followed to prepare subthalamic neurons (see above).

Sympathetic neurons were prepared from 9- to 13-d-old rats (Boland et al., 1994; McDonough et al., 1997a). The ganglia were dissected out in ice-cold oxygenated Leibovitz's L-15 medium solution (Life Technologies; reference 11415-064). Each ganglion was cut into two or three pieces before being incubated for $20 \mathrm{~min}$, at $35^{\circ} \mathrm{C}$, in a calcium-free Tyrode's solution that contained (in $\mathrm{mM}$ ): $150 \mathrm{NaCl}, 4 \mathrm{KCl}, 2 \mathrm{MgCl}_{2}, 10$ glucose, and $10 \mathrm{Na}-\mathrm{HEPES}$, plus $25 \mathrm{U} / \mathrm{ml}$ papain (Worthington Biochemicals, Lakewood, NJ), $0.5 \mathrm{~mm}$ EDTA, and $2 \mathrm{~mm}$ L-cysteine, pH 7.4 with $\mathrm{NaOH}$. After this first incubation, the ganglia were transferred into a calcium-free Tyrode's solution containing $2 \mathrm{mg} / \mathrm{ml}$ collagenase (type I) and $8 \mathrm{mg} / \mathrm{ml}$ dispase (Boehringer Mannheim, Indianapolis, IN). This incubation was performed at $35^{\circ} \mathrm{C}$ for $40 \mathrm{~min}$. The ganglia were then rinsed, and the cells were released in the MEM solution, which contained $10 \mathrm{mM}$ Na-HEPES, $15 \mathrm{~mm}$ glucose, $1 \mathrm{mg} / \mathrm{ml}$ bovine serum albumin, and $1 \mathrm{mg} / \mathrm{ml}$ trypsin inhibitor $\left(36^{\circ} \mathrm{C}, \mathrm{pH} 7.4\right.$ with $\left.\mathrm{NaOH}\right)$

Isolated neurons were stored at room temperature $\left(18-22^{\circ} \mathrm{C}\right)$ and remained viable for $5-8 \mathrm{hr}$.

Voltage-clamp recordings. Patch-clamp recordings of $\mathrm{Ca}$ channel currents were performed in the whole-cell configuration using $\mathrm{Ba}^{2+}$ ions $(5 \mathrm{~mm})$ as the charge carrier. Patch pipettes $(\sim 2 \mathrm{M} \Omega)$ were pulled from borosilicate glass capillaries (Fisher Scientific, Suwane, GA), coated with Sylgard, and fire-polished. In all the recordings used in this report, the capacitance and the access series resistance were compensated to minimize the voltage errors to $<5 \mathrm{mV}$. Three to $10 \mathrm{G} \Omega$ seals were routinely obtained, allowing the data to be presented without leak correction. Measurements of current block by the different toxins were performed without correcting for current rundown. In most experiments, at least 10 min elapsed between the onset of the whole-cell recording and the beginning of the experiment to allow the initial current rundown to stabilize. After stabilization, current rundown was typically $<10 \%$ over the complete course of the experiment (usually $1-2 \mathrm{hr}$ ).

Whole-cell currents were recorded using an Axopatch 200B amplifier (Axon Instruments, Foster City, CA). Voltage step commands and data acquisition were controlled using the XOP Pulse Control (Herrington and Bookman, 1994; http/chroma.med.miami.edu/cap) in IGOR (WaveMetrics, Lake Oswego, OR) and an ITC16 analog-to-digital converter (Instrutech Corp., Great Neck, NY). The currents were digitized every 100 $\mu \mathrm{sec}$ and filtered at $2 \mathrm{kHz}$. All potentials were corrected for a liquid junction potential of $-10 \mathrm{mV}$ between the internal recording solution and the Tyrode's solution in which the pipette current was zeroed before establishing the seal.

Data analysis and illustration were performed with IGOR. Statistics are given as mean \pm SEM.

Solutions. The solution in the recording patch pipette contained (in $\mathrm{mM}$ ): 108 cesium methanesulfonate, $4 \mathrm{MgCl}_{2}, 9$ EGTA, 9 HEPES (acid), 4 Mg-ATP, $0.3 \mathrm{~mm}$ GTP (Tris salt), and 14 creatine phosphate (Tris salt), $\mathrm{pH} 7.4$ with $\mathrm{CsOH}$. For studies of $\mathrm{K}$ channel currents, $\mathrm{Cs}^{+}{ }^{+}$was replaced with $\mathrm{K}^{+}$

The extracellular solution contained (in $\mathrm{mM}$ ): 160 tetraethylammonium (TEA)-Cl, $5 \mathrm{BaCl}_{2}, 10 \mathrm{HEPES}$, and 0.1 EGTA, pH 7.4 with TEAOH, and
Rat subthalamic neuron

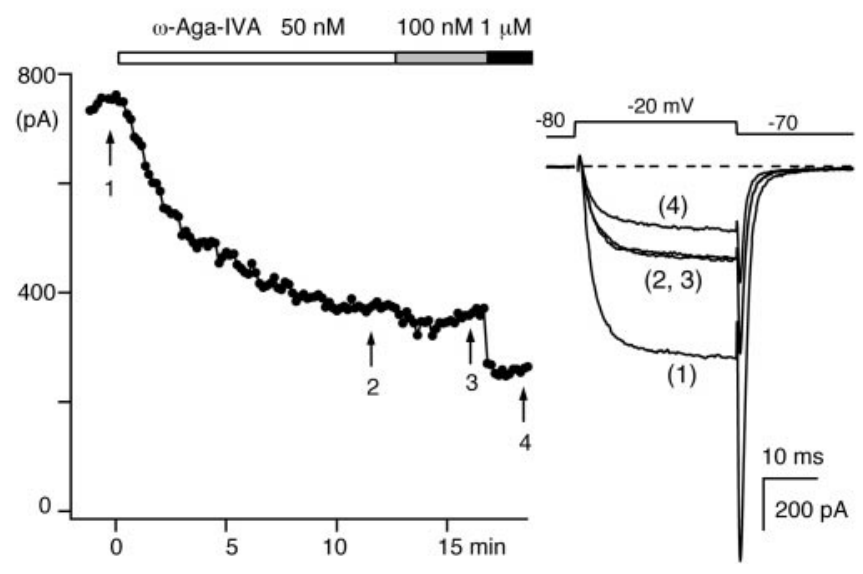

Figure 1. Subthalamic neuron Ca channel currents blocked by increasing concentrations of the spider toxin $\omega$-Aga-IVA. Each data point represents the peak current elicited by a test pulse from -80 to $-20 \mathrm{mV}$ at $10 \mathrm{sec}$ intervals. Inset, Representative current traces in control conditions (1) and in the presence of $50 \mathrm{~nm}(2), 100 \mathrm{~nm}$ (3), and $1 \mu \mathrm{M}$ (4) $\omega$-Aga-IVA.

$1 \mathrm{mg} / \mathrm{ml}$ cytochrome $c$. For studies of $\mathrm{Na}$ and $\mathrm{K}$ channel currents, the extracellular solution was regular Tyrode's solution, which contained (in $\mathrm{mm}$ ): $150 \mathrm{NaCl}, 4 \mathrm{KCl}, 2 \mathrm{CaCl}_{2}, 2 \mathrm{MgCl}_{2}$, and 10 glucose, $\mathrm{pH} 7.4$ with $\mathrm{NaOH}$, as well as $1 \mathrm{mg} / \mathrm{ml}$ cytochrome $c$.

Stock solutions of $(100 \mu \mathrm{M})$ nimodipine [Research Biochemicals International (RBI); Sigma] and Bay K 8644 (RBI) were prepared in DMSO and stored in the dark. A $0.5 \mathrm{~mm}$ solution of $\omega$-CgTX and a $100 \mu \mathrm{M}$ stock solution of $\omega$-Aga-IVA (Peptide Institute, Osaka, Japan; or free samples kindly provided by Pfizer Inc., Groton, CT) were prepared in distilled water. The stock solution with $\omega$-Aga-IVA was aliquoted in $10 \mu \mathrm{l}$ samples to minimize the number of thawing and freezing cycles for a single vial These aliquots were stored at $-80^{\circ} \mathrm{C}$. The peptide $\omega$-Aga-IVA obtained from the Peptide Institute or Pfizer showed identical potency and selectivity.

Concentrated $10 \times$ solutions, to be added to the recording mini-chamber, were prepared by diluting the stock solutions in the standard Tyrode's solution (for $\mathrm{Na}$ or $\mathrm{K}$ current recordings) or in the $\mathrm{Ba}^{2+}(5 \mathrm{mM})$-containing TEA solution (for $\mathrm{Ca}$ channel current recordings). All $10 \times$ solutions also contained $1 \mathrm{mg} / \mathrm{ml}$ cytochrome $c$.

The pipette tips, the recording chamber, and the vials that contained the toxin stock and $10 \times$ solutions were all siliconized to prevent toxin loss through nonspecific binding.

Drug application. All cells were recorded in a $100 \mu \mathrm{l}$ mini-chamber. Small volumes of concentrated $(10 \times)$ toxin solutions were pipetted into the mini-chamber to expose the recorded cell to high concentrations with minimal amounts of the toxins being used.

A small inlet and outlet were used to exchange the external solution in the mini-chamber when recovery from toxin block was studied. When compared with more conventional application techniques (such as the use of arrays of "sewer" pipes), this experimental procedure leads to accurate measurements of steady-state current block. However, the time course of current block observed when toxins are applied directly into the recording chamber was too variable to provide useful kinetic information.

All experiments were done at room temperature $\left(18-22^{\circ} \mathrm{C}\right)$.

\section{RESULTS}

\section{$\omega$-Aga-IVA block of multiple Ca current components}

In subthalamic neurons, the spider toxin $\omega$-Aga-IVA blocked more than one Ca channel current (Fig. 1). In the experiment of Figure 1 , Ca channel currents carried by $5 \mathrm{mM} \mathrm{Ba}^{2+}$ were elicited every 10 sec by a $30 \mathrm{msec}$ voltage step from -80 to $-20 \mathrm{mV}$. Within $10 \mathrm{~min}$ of $\omega$-Aga-IVA application (50 nM final concentration), the control current was reduced by $51 \%$. Raising the toxin concentration to $100 \mathrm{~nm}$ had little if any effect, indicating a saturating block of this current component by $50 \mathrm{~nm} \omega$-Aga-IVA $(n=3)$. In the same cell, further increase of $\omega$-Aga-IVA concentration from $100 \mathrm{~nm}$ to $1 \mu \mathrm{M}$ produced an additional current reduction, which amounted to $\sim 16 \%$ of the control current. In five similar experiments, 50-100 nM $\omega$-Aga-IVA inhibited $50.4 \pm 3.4 \%$ of the control current, whereas its subsequent application at $1 \mu \mathrm{M}$ blocked $14.0 \pm 1.7 \%$ of the total current. These data suggest that $\omega$-Aga-IVA targets at 
A

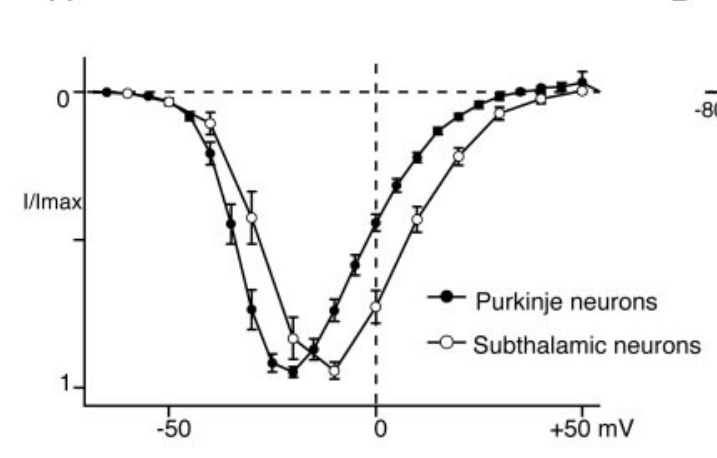

D1 Purkinje neuron

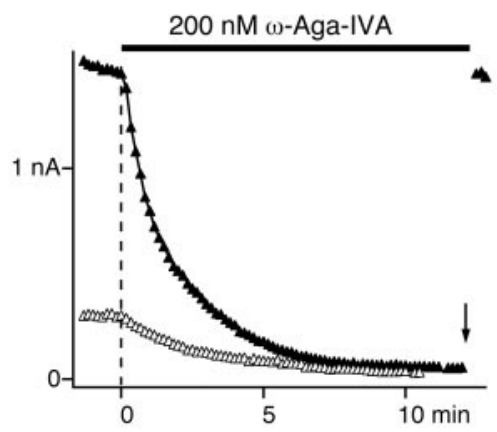

B

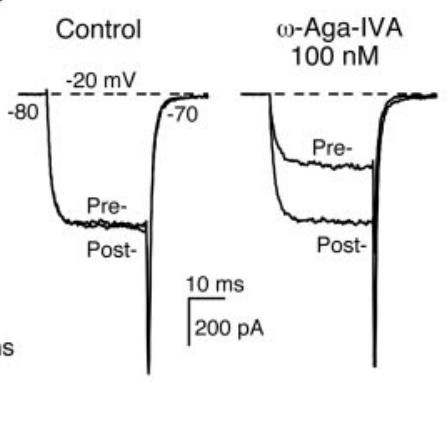

C

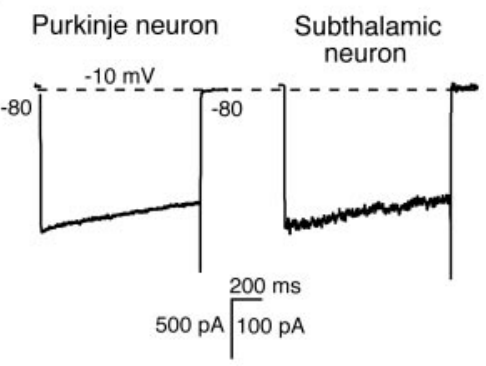

D2 Subthalamic neuron



$\omega$-Aga-IVA-sensitive current

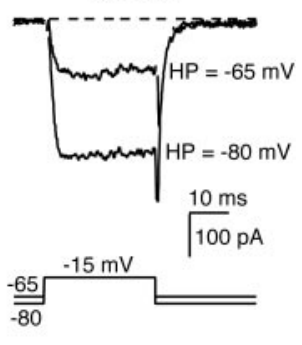

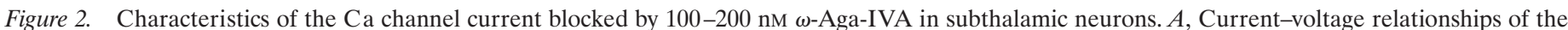

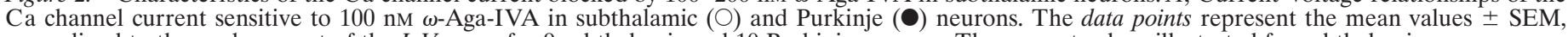

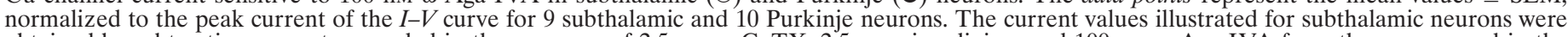

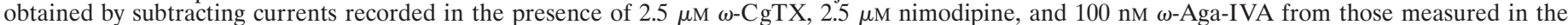

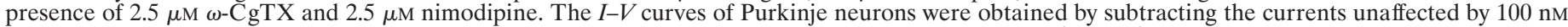

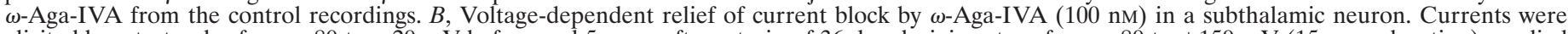

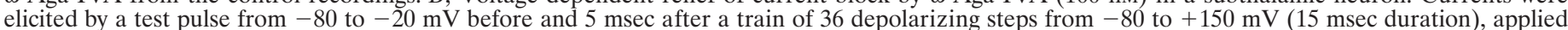

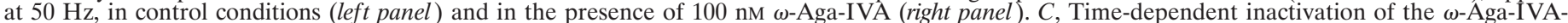

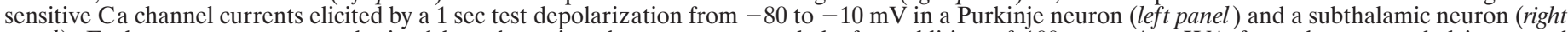

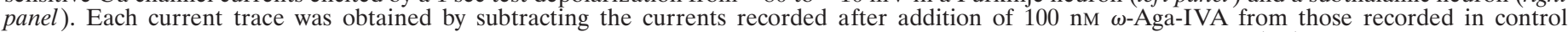

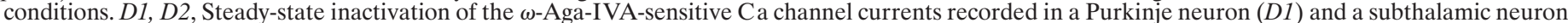

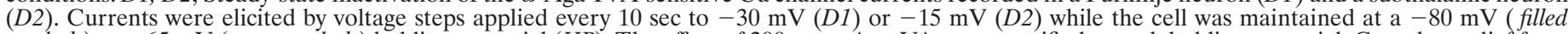

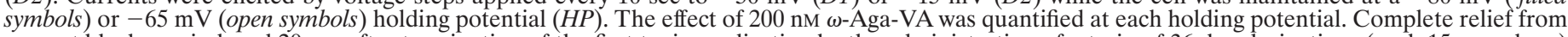

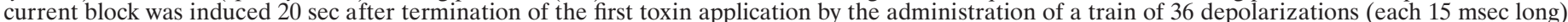

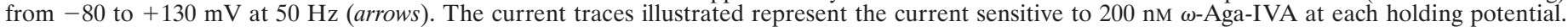
These traces were obtained by subtracting currents recorded after addition of the toxin from the control currents.

least two populations of $\mathrm{Ca}$ channels, blocking one with high potency and the other with lower potency.

\section{P-type current block in Purkinje and subthalamic neurons}

Figure 2 compares the basic properties of the subthalamic current targeted by nanomolar concentrations of $\omega$-Aga-IVA (50-200 nM) with those of the P-type Ca current recorded in Purkinje neurons.

\section{Voltage-dependent activation}

Figure $2 A$ illustrates the current-voltage relationships of the $\omega$-Aga-IVA-sensitive current in Purkinje and subthalamic neurons. Currents were elicited by $20 \mathrm{msec}$ depolarization steps applied from $-80 \mathrm{mV}$ to different voltages. For each test pulse, the $\omega$-AgaIVA-sensitive current was determined by subtracting the $\omega$-AgaIVA-resistant current from the control recordings and measuring its peak. The data points represent averages \pm SEM of such measurements for 8 Purkinje cells and 10 subthalamic neurons. The P-type $\mathrm{Ca}$ current in Purkinje neurons activated at more negative potentials than did its counterpart in subthalamic neurons. Consistent with a previous report (Regan, 1991), the $I-V$ curve in Purkinje neurons peaked at approximately $-20 \mathrm{mV}$. In contrast, in subthalamic neurons, the current affected by $100 \mathrm{~nm} \omega$-Aga-IVA was maximal at approximately $-10 \mathrm{mV}$.

\section{Voltage-dependent unblock}

A strong voltage dependence of the off rate characterizes the high-affinity binding of $\omega$-Aga-IVA to P-type Ca channels (Mintz et al., 1992; McDonough et al., 1997). This property results in the complete unblock of P-type Ca current at positive potentials $(>120$ $\mathrm{mV}$ ). In Figure $2 B$, control currents were elicited, in a subthalamic neuron, by a -80 to $-20 \mathrm{mV}$ test pulse. They were unaffected by trains of large depolarizations (Fig. 2B, left panel). After the administration of $100 \mathrm{~nm} \omega$-Aga-IVA and the resulting $43 \%$ current reduction, the application of the identical train of depolarizations restored the test current back to its control value (Fig. $2 \mathrm{~B}$, right panel).

\section{Time-dependent inactivation}

A characteristic of P-type Ca current in Purkinje neurons is its slow inactivation during prolonged test pulses (Regan, 1991; Usowicz et al., 1992; Dove et al., 1998). We compared the kinetics of $\omega$-AgaIVA-sensitive currents in a Purkinje cell (Fig. 2C, left, $200 \mathrm{~nm}$ $\omega$-Aga-IVA) and in a subthalamic neuron (Fig. 2C, right, $50 \mathrm{~nm}$ $\omega$-Aga-IVA). In both cases, currents were elicited by a 1 sec test pulse applied from -80 to $-10 \mathrm{mV}$. Once their amplitude were normalized, the current traces were superimposable. 


\section{Steady-state inactivation}

P-type $\mathrm{Ca}$ channels in cerebellar granule cells display dramatic steady-state inactivation (Tottene et al., 1996). Using the same approach, we have investigated the inactivation properties of the $\omega$-Aga-IVA-sensitive current in subthalamic neurons $(n=3)$ and in Purkinje cells $(n=4)$. Representative recordings are illustrated in Figure 2, D1 (Purkinje neuron) and D2 (subthalamic neuron). In both cases, $\omega$-Aga-IVA was first tested on currents elicited by 30 msec pulses applied from -80 to $-30 \mathrm{mV}$ (Purkinje neuron) or $-15 \mathrm{mV}$ (subthalamic neuron). The application was maintained for $>6$ min to ensure steady-state current block. The toxin was then washed out of the mini-chamber, and we applied large depolarizations to facilitate current recovery to its control value. The cell holding potential was then changed from -80 to $-65 \mathrm{mV}$, and current was again elicited by $30 \mathrm{msec}$ steps to $-30 \mathrm{mV}$ (Purkinje neuron) or $-15 \mathrm{mV}$ (subthalamic neuron). Pronounced current inactivation occurred within 6-8 min of changing the holding potential. $\omega$-Aga-IVA was then reapplied to quantify the fraction of P-type $\mathrm{Ca}$ current that escaped inactivation. In both cell types, we found a significant reduction in the amplitude of the current affected by $\omega$-Aga-IVA. A change in holding potential from -80 to $-65 \mathrm{mV}$ inactivated between 40 and $80 \%$ of the P-type Ca current in Purkinje neurons $(n=4)$ and between 45 and $75 \%$ of the P-type Ca current in subthalamic neurons $(n=4)$.

We were unable to complete the inactivation curve of P-type $\mathrm{Ca}$ channels in Purkinje and subthalamic neurons. In both cell types, it was difficult to reverse steady-state current inactivation. Moreover, current runup in Purkinje neurons and current rundown in subthalamic neurons often interfered with a precise estimate of inactivation.

Overall, we found that the subthalamic current inhibited by nanomolar concentrations of $\omega$-Aga-IVA was very similar to Purkinje neuron P-type $\mathrm{Ca}$ current. Except for a slight difference in their voltage-dependent activation, both currents were identical. They displayed little time-dependent inactivation during a 1-seclong test depolarization (Fig. $2 C$ ) but showed considerable steadystate inactivation at holding potentials as negative as $-65 \mathrm{mV}$ (Fig. $2 D 1, D 2)$. In subthalamic as in Purkinje neurons, the efficacy of toxin block was voltage-dependent (Fig. $2 B$ ). On the basis of these similarities, despite the absence of structural data, we now refer to the subthalamic Ca current affected by $\omega$-Aga-IVA (100 nM) as the subthalamic P-type Ca current.

Subsequent experiments investigate the current component targeted by micromolar concentrations of $\omega$-Aga-IVA.

\section{$\omega$-Aga-IVA selectivity}

To verify the toxin selectivity when it is used in the micromolar range, we tested its effects on a variety of identified voltage-gated ion currents.

In subthalamic neurons, $\omega$-Aga-IVA $(1 \mu \mathrm{M})$ had no effect voltage-gated $\mathrm{Na}$ currents $(n=4)$. As shown in Figure $3 A$, the $\mathrm{Na}$ current elicited by a voltage step from -80 to $-30 \mathrm{mV}$ was identical before and $6 \mathrm{~min}$ after toxin application. It did not affect voltagegated $\mathrm{K}$ currents either $(n=4)$. In Figure $3 B$, using another subthalamic neuron, a similar K current was recorded during a -80 to $-10 \mathrm{mV}$ voltage-step before and after toxin application $(1 \mu \mathrm{M}$ for $1 \mathrm{~min})$.

We then tested the effects of $\omega$-Aga-IVA $(1 \mu \mathrm{M})$ on identified $\mathrm{Ca}$ currents.

The application of $\omega$-Aga-IVA $(1 \mu \mathrm{M})$ had no effect on the low-threshold T-type currents recorded in subthalamic neurons $(n=3)$. In Figure $3 C$, left, $\omega$-Aga-IVA $(1 \mu \mathrm{M})$ spared the lowthreshold current activated by a -100 to $-55 \mathrm{mV}$ voltage-step and the slowly deactivating T-type tail current. In the same cell, it reduced the high-threshold currents elicited from a less negative holding potential by $56 \%$ (Fig. 3C, right).

L-type currents enhanced with the dihydropyridine agonist Bay K $8644(3 \mu \mathrm{M})$ were equally insensitive to $\omega$-Aga-IVA $(1 \mu \mathrm{M} ; n=$ 5). After treatment with Bay K $8644(3 \mu \mathrm{M})$, the threshold for activation of L-type $\mathrm{Ca}$ channels is decreased, and their mean

\section{Rat subthalamic neurons}

A Na current

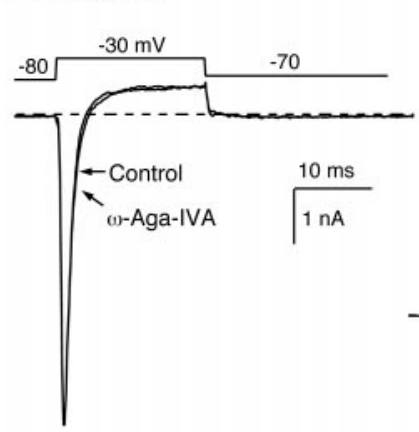

B K current

C T-type Ca channel current


D L-type Ca channel current

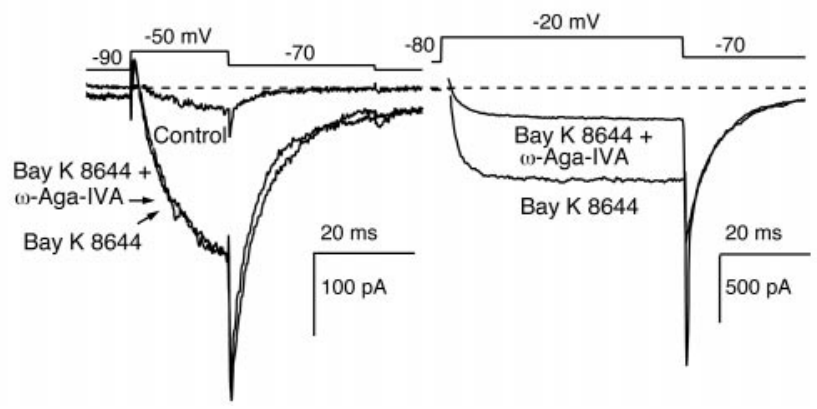

Figure 3. Insensitivity of subthalamic $\mathrm{Na}, \mathrm{K}$, and $\mathrm{Ca}$ ( $\mathrm{T}$ - and L-type) currents to $1 \mu \mathrm{M} \omega$-Aga-IVA. $A, \omega$-Aga-IVA $(1 \mu \mathrm{M})$ effect on the Na current elicited by a test depolarization from -80 to $-30 \mathrm{mV}$. Extracellular $\mathrm{Cd}^{2+}$ $(0.5 \mathrm{mM})$ was present throughout the recordings to suppress $\mathrm{Ca}$ channel currents. Addition of $1 \mu \mathrm{M}$ TTX, at the end of the experiment, abolished all voltage-gated inward currents (data not illustrated). $B$, $\omega$-Aga-IVA (1 $\mu \mathrm{M})$ effect on the $\mathrm{K}$ current elicited by a test pulse from -80 to $+60 \mathrm{mV}$. The extracellular solution contained $1 \mu \mathrm{M}$ TTX and $0.5 \mathrm{mM} \mathrm{Cd}^{2+}$ to block Na and $\mathrm{Ca}$ currents. $C, \omega$-Aga-IVA $(1 \mu \mathrm{M})$ effect on low-threshold T-type $\mathrm{Ca}$ currents. A small test pulse from -100 to $-55 \mathrm{mV}$ elicited a low-threshold, slowly deactivating T-type current that was unaffected by exposure to $1 \mu \mathrm{M}$ $\omega$-Aga-IVA (left panel). Right panel, Effect, in the same cell, of $1 \mu \mathrm{M}$ $\omega$-Aga-IVA on high-threshold $\mathrm{Ca}$ channel currents elicited by a larger depolarization from -80 to $-30 \mathrm{mV}$. D, $\omega$-Aga-IVA $(1 \mu \mathrm{M})$ effect on Bay $\mathrm{K}$ 8644-enhanced L-type Ca currents. The currents illustrated in the left panel were elicited by a small depolarization applied from -90 to $-50 \mathrm{mV}$ in control conditions, after addition of Bay $\mathrm{K} 8644(3 \mu \mathrm{M})$, and in the presence of Bay K $8644(3 \mu \mathrm{M})$ plus $\omega$-Aga-IVA $(1 \mu \mathrm{M})$. In the same cell (right panel), high-threshold Ca currents elicited by a -80 to $-20 \mathrm{mV}$ step depolarization were inhibited by $1 \mu \mathrm{M} \omega$-Aga-IVA. The data presented were obtained in different subthalamic neurons.

open time is increased, resulting in the appearance of a lowthreshold current and slowly deactivating tail currents (Fig. 3D, left). These currents, exclusively carried through L-type Ca channels, did not change after a 6 min exposure to $\omega$-Aga-IVA $(1 \mu \mathrm{M})$. In the same cell, the reduction of other high-threshold currents confirmed the efficacy of the toxin application (Fig. 3D, right).

These data suggest that the toxin $\omega$-Aga-IVA remains selective in the micromolar range. However, our subsequent investigation of its effect on $\mathrm{N}$-type $\mathrm{Ca}$ currents demonstrated that this selectivity is not complete. 
Rat sympathetic neurons
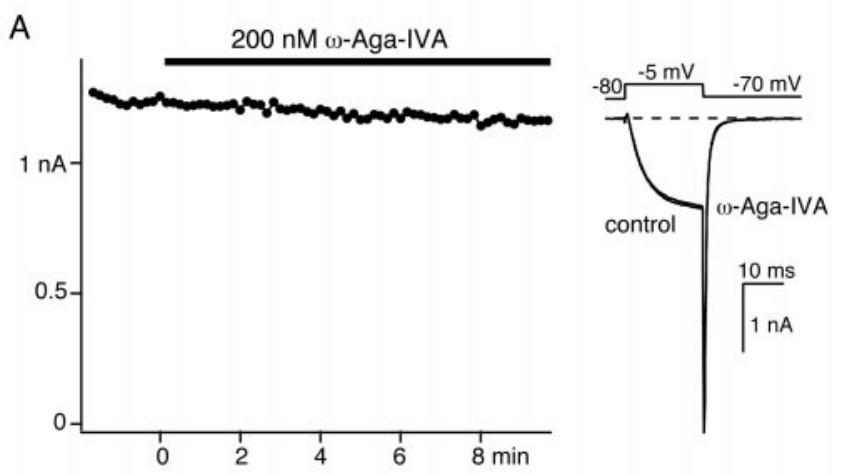

B

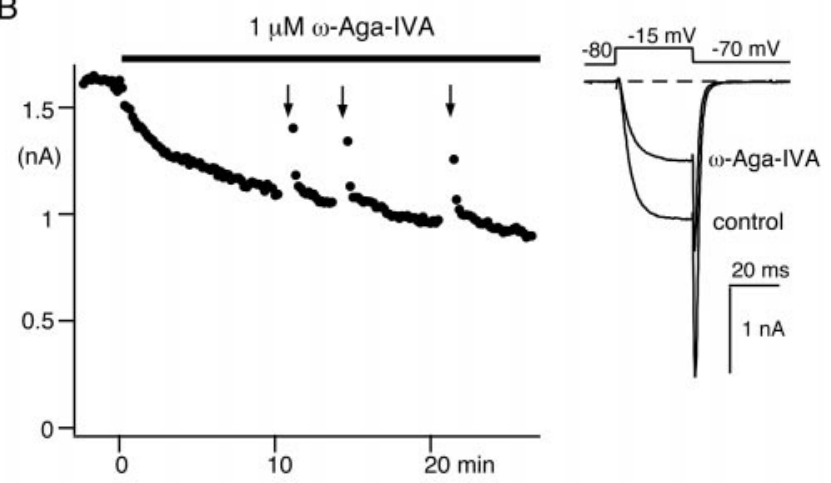

C

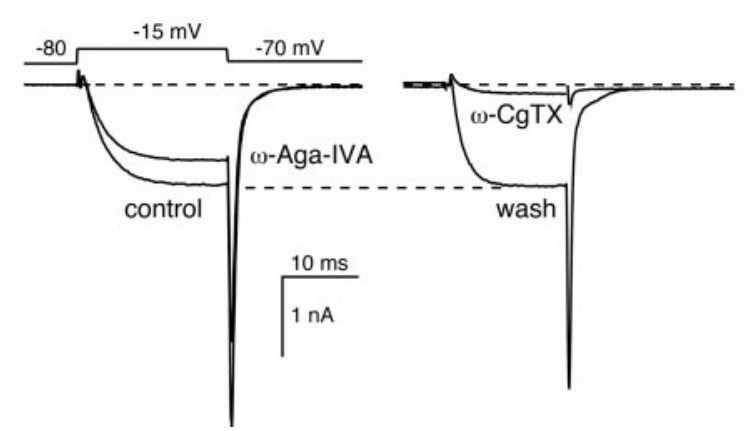

Figure 4. Block of N-type Ca channel current by $1 \mu \mathrm{M} \omega$-Aga-IVA in sympathetic neurons. $A$, Lack of effect of $200 \mathrm{~nm} \omega$-Aga-IVA on the Ca channel current recorded in a sympathetic neuron. Time course of the peak current elicited by voltage steps applied from -80 to $-5 \mathrm{mV}$ every $10 \mathrm{sec}$ (left panel) and representative current traces (right panel) are shown. B, Ca channel current block produced by $1 \mu \mathrm{M} \omega$-Aga-IVA. Time course (left panel) and representative current traces (right panel) elicited by voltagesteps from -80 to $-15 \mathrm{mV}$ at $10 \mathrm{sec}$ intervals are shown. Nimodipine (2.5 $\mu \mathrm{M})$ was present throughout the experiment. Arrows (left panel) indicate the application of a $50 \mathrm{~Hz}$ train of 70 depolarizing steps from -80 to +120 $\mathrm{mV}$ (each 15 msec duration). $C$, Reversibility of N-type current block by 1 $\mu \mathrm{M} \omega$-Aga-IVA. Left panel, Current traces elicited by a voltage step from -80 to $-15 \mathrm{mV}$ in control conditions and $15 \mathrm{~min}$ after addition of $1 \mu \mathrm{M}$ $\omega$-Aga-IVA. Right panel, Current recordings were elicited by similar test pulses 5 min after wash of $\omega$-Aga-IVA and 2 min after subsequent addition of $2.5 \mu \mathrm{M} \omega-\mathrm{CgTX}$. The experiments were performed in different sympathetic neurons.

\section{$\omega$-Aga-IVA block of $\mathrm{N}$-type Ca currents \\ Sympathetic neurons}

We tested the block of N-type $\mathrm{Ca}$ channels in rat sympathetic neurons, in which up to $90 \%$ of the $\mathrm{Ca}$ channel current is carried through $\omega$-CgTX-sensitive N-type channels. As shown previously (Mintz et al., 1992), 200 nм $\omega$-Aga-IVA had no effect on the Ca channel current recorded in these cells. In Figure $4 A$, the small reduction of the current elicited by a voltage step from -80 to -5 $\mathrm{mV}$ was indistinguishable from current rundown $(n=4)$. In contrast, significant current reduction was observed after applications of $\omega$-Aga-IVA $(1 \mu \mathrm{M})$ (Fig. $4 B)$. In this experiment, the small L-type current component ( $<2 \%$ of the control current) was blocked with nimodipine $(2.5 \mu \mathrm{M})$. The subsequent application of $\omega$-Aga-IVA $(1 \mu \mathrm{M})$ produced a slow and significant current inhibition. On average, a $10 \mathrm{~min}$ application of the toxin reduced the control current by $28.2 \pm 2.2 \%(n=11)$. This effect was completely reversible. The Ba current returned to its control value within 1 min of toxin washout; its sensitivity to $\omega$-CgTX confirmed its identification as an N-type Ca channel current (Fig. 4C).

We tested the voltage dependence of $\omega$-Aga-IVA N-type current block using trains of 70 pulses to $+150 \mathrm{mV}$ as they produced maximal unblock of the subthalamic current fraction inhibited by $100 \mathrm{~nm} \omega$-Aga-IVA. There was considerable variability in the results. Such trains had almost no effect in some sympathetic neurons but produced significant unblock in others. Reliable unblock of the sympathetic N-type current consistently required stronger and more numerous depolarizations than necessary for the relief of P-type $\mathrm{Ca}$ current block in subthalamic neurons. Typically (Fig. 4B, arrows), partial unblock of the N-type current was best demonstrated after relatively mild depolarizations (here 70 pulses to $+120 \mathrm{mV}$ ). Larger depolarizations elicited significant inactivation of the control current, which then obscured the relief of the current blockade.

\section{Subthalamic neurons}

Because the pharmacology of $\mathrm{Ca}$ channels in peripheral and central neurons may differ, we then investigated the effect of $\omega$-AgaIVA $(1 \mu \mathrm{M})$ on subthalamic neuron $\mathrm{N}$-type Ca current. To test for overlap in the Ca current components blocked by $\omega$-Aga-IVA (1 $\mu \mathrm{M})$ and $\omega$-CgTX $(2.5 \mu \mathrm{M})$, two sets of experiments were performed in alternate recordings of subthalamic neurons $(n=20)$. In one set, we quantified the effect of $\omega$-Aga-IVA $(1 \mu \mathrm{M})$ first and then measured the additional current block produced by $\omega$-CgTX $(2.5$ $\mu \mathrm{M})$ plus $\omega$-Aga-IVA $(1 \mu \mathrm{M})$. In the other set, toxins were applied in reverse order. We measured the effect of $\omega$-CgTX $(2.5 \mu \mathrm{M})$ first and the effect of coapplication of the toxins second.

In Figure 5, $A$ and $B$, the data points illustrate the time course of the $\mathrm{Ba}$ current recorded in control conditions, during the application of $\omega$-Aga-IVA alone (Fig. $5 A$ ) or $\omega$-CgTX alone (Fig. $5 B$ ), and during the coapplication of $\omega$-Aga-IVA $(1 \mu \mathrm{M})$ and $\omega$-CgTX $(2.5$ $\mu \mathrm{M})$. The corresponding current traces are depicted in the insets. In both experiments, the Ba current was activated every $10 \mathrm{sec}$ by a -80 to $-15 \mathrm{mV}$ voltage step. Because $\omega$-CgTX-sensitive Ca currents are more susceptible to rundown than other voltage-gated $\mathrm{Ca}$ currents (our unpublished data), drug applications were timed to ensure that the $\omega$-CgTX effect was measured after the same length of recordings in both experimental conditions $(\sim 6 \mathrm{~min}$ after time 0).

On average, $\omega$-Aga-IVA blocked $55.9 \pm 2.5 \%$ of the control current. This effect was reduced to $40.7 \pm 2.1 \%$ when it was measured after N-type current block with $\omega$-CgTX (Fig. 5C), suggesting that $\sim 27 \%$ of the $\omega$-Aga-IVA-sensitive current is also sensitive to $\omega$-CgTX. The toxin $\omega$-Aga-IVA interfered in a similar manner with $\omega$-CgTX block of the N-type current component. Applied alone, $\omega$-CgTX inhibited $47.6 \pm 1.8 \%$ of the control current. This $\omega$-CgTX-sensitive current fraction was reduced to $33.1 \pm 1.7 \%$ of the control current when $\omega$-CgTX was tested after the application of $\omega$-Aga-IVA $(1 \mu \mathrm{M})$. Such overlap between the $\omega$-Aga-IVA- and $\omega$-CgTX-sensitive current components suggests that $\omega$-Aga-IVA $(1 \mu \mathrm{M})$ also targets $\mathrm{N}$-type $\mathrm{Ca}$ channels in subthalamic neurons. Our numbers indicate that $\omega$-Aga-IVA $(1 \mu \mathrm{M})$ blocked $\sim 30 \%$ of the $\omega$-CgTX-sensitive N-type Ca channel current in subthalamic neurons, a value remarkably similar to the magnitude of its effect on $\mathrm{N}$-type current in sympathetic neurons. 
Rat subthalamic neurons
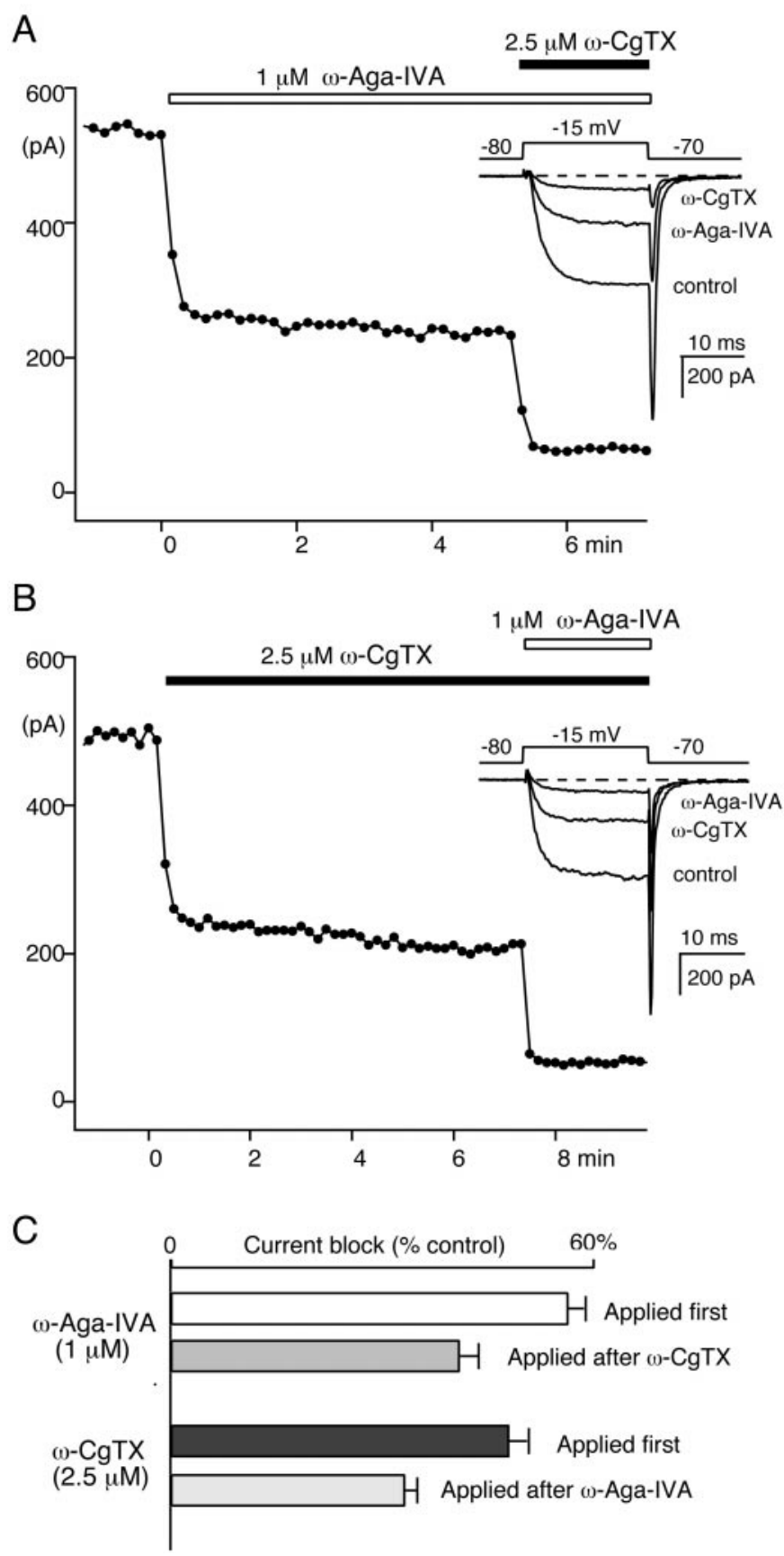

Figure 5. Block of N-type Ca channel current by $1 \mu \mathrm{M} \omega$-Aga-IVA in subthalamic neurons. $A$, Ca channel current block by $1 \mu \mathrm{M} \omega$-Aga-IVA followed by $1 \mu \mathrm{M} \omega$-Aga-IVA plus $2.5 \mu \mathrm{M} \omega$-CgTX. $B$, In another rat subthalamic neuron, $\mathrm{Ca}$ channel current block by $2.5 \mu \mathrm{M} \omega$-CgTX followed by $2.5 \mu \mathrm{M} \omega$-CgTX plus $1 \mu \mathrm{M} \omega$-Aga-IVA. In $A$ and $B$, the data points represent the time course of the peak current elicited every $10 \mathrm{sec}$ by a 20 msec test pulse from -80 to $-15 \mathrm{mV}$. Insets, Corresponding current traces. $C$, Average currents blocked by $\omega$-CgTX and $\omega$-Aga-IVA in 12 experiments performed as in $A$ and 8 experiments performed as in $B$. The top two bars illustrate the current fractions blocked by $1 \mu \mathrm{M} \omega$-Aga-IVA applied alone (white bar) or after preblock of N-type Ca channels with $2.5 \mu \mathrm{M} \omega$-CgTX (gray bar). The bottom two bars represent the current fractions blocked by $2.5 \mu \mathrm{M} \omega$-CgTX applied alone (black bar) or after application of $1 \mu \mathrm{M}$ $\omega$-Aga-IVA (striped bar).

\section{Block of other Ca channels by micromolar concentrations of $\omega$-Aga-IVA}

In some subthalamic neurons $(n=14)$, a large enough current remained unaffected after blockade of L-, N-, and P-type Ca

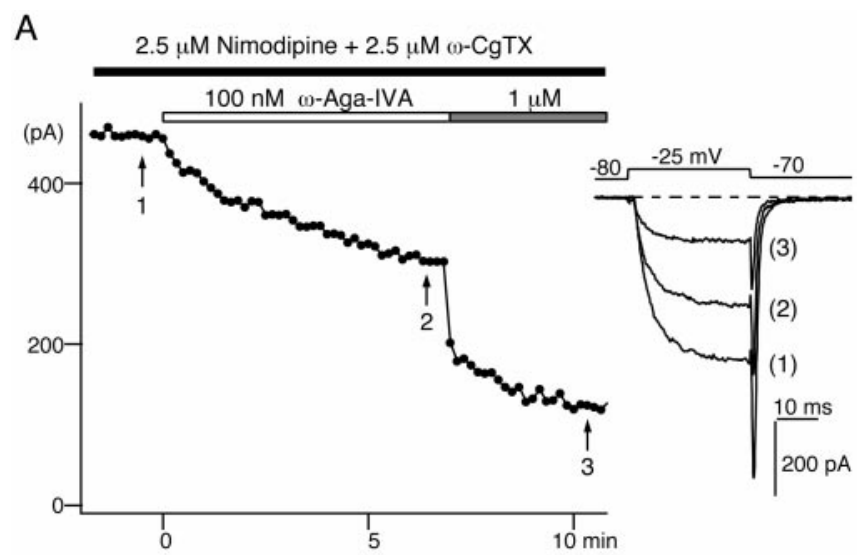

B

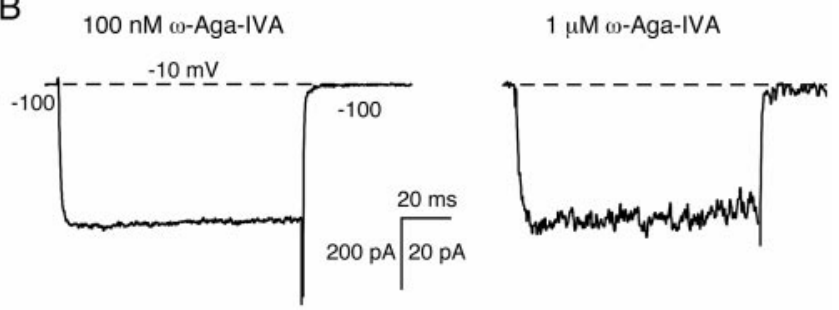

Figure 6. Ca channel current inhibited by $1 \mu \mathrm{M} \omega$-Aga-IVA after block of $\mathrm{L}-, \mathrm{N}$-, and P-type Ca channel currents in subthalamic neurons. $A$, Each data point represents the peak current elicited by a voltage-step from -80 to $-25 \mathrm{mV}$ at $10 \mathrm{sec}$ intervals. The current traces illustrated in the left panel were recorded in the presence of $2.5 \mu \mathrm{M}$ nimodipine and $2.5 \mu \mathrm{M} \omega$-CgTX after addition of $100 \mathrm{~nm} \omega$-Aga-IVA and after subsequent increase of $\omega$-Aga-IVA concentration to $1 \mu \mathrm{M}$. $B$, Comparison of the current components affected by $100 \mathrm{~nm} \omega$-Aga-IVA (left) and $1 \mu \mathrm{M} \omega$-Aga-IVA (right) in a similar experiment performed, on another subthalamic neuron, in the continuous presence of $2.5 \mu \mathrm{M}$ nimodipine and $2.5 \mu \mathrm{M} \omega$-CgTX. Currents were elicited by a $100 \mathrm{msec}$ depolarizing step from -100 to $-10 \mathrm{mV}$. The current traces illustrated here were obtained by subtraction.

currents for its sensitivity to micromolar concentrations of $\omega$-AgaIVA to be assessed.

Figure $6 \mathrm{~A}$ illustrates the time course of the Ba currents elicited by a -80 to $-25 \mathrm{mV}$ step depolarization applied every $10 \mathrm{sec}$. The recordings were performed in the continuous presence of nimodipine $(2.5 \mu \mathrm{M})$ and $\omega$-CgTX $(2.5 \mu \mathrm{M})$. A $100 \mathrm{~nm} \omega$-Aga-IVA was first applied to produce saturating block of the P-type current. Subsequent increase of the toxin concentration to $1 \mu \mathrm{M}$ resulted in additional current block, which represented $20.0 \pm 2.9 \%$ of the current recorded in the presence of nimodipine and $\omega-\operatorname{CgTX}(n=$ 14). There was considerable variability in the amplitude of this current component, which did not correlate with that of the P-type $\mathrm{Ca}$ current. This current could be large in cells endowed with a relatively small P-type current component and vice versa, suggesting that different $\mathrm{Ca}$ channel types underlie these two currents. We conclude that subthalamic neurons express a high-threshold current, which is distinct from the P-type current component and which displays the pharmacological properties of the Q-type $\mathrm{Ca}$ current in cerebellar granule cells.

Rapid inactivation is a characteristic of the prototypic Q-type $\mathrm{Ca}$ current described in cerebellar granule cells (Randall and Tsien, 1995). In the experiment illustrated in Figure $6 B$, we evaluated this parameter for the $\omega$-Aga-IVA-sensitive currents of subthalamic neurons. As in Figure $6 A$ but in a different subthalamic neuron, $\omega$-CgTX $(1 \mu \mathrm{M})$ and nimodipine $(2.5 \mu \mathrm{M})$ were present throughout the experiment to ensure blockade of the $\mathrm{N}$ - and L-type $\mathrm{Ca}$ currents. To maximize the transient components, we used a very negative holding potential $(-100 \mathrm{mV})$ and longer $(100$ msec duration) test pulses. The currents were studied in control conditions, after addition of $100 \mathrm{~nm} \omega$-Aga-IVA, and after further increase of the toxin concentration to $1 \mu \mathrm{M}$. Both currents, deter- 
mined by subtraction, showed little time-dependent inactivation during test depolarizations. After proper scaling, they were nearly superimposable.

\section{DISCUSSION}

\section{Toxin selectivity}

Our data confirm the initial description of the toxin $\omega$-Aga-IVA as a potent and selective blocker of P-type $\mathrm{Ca}$ channels. As documented in other cell types (Bargas et al., 1994; Brown et al., 1994; Eliot and Johnston, 1994; Tottene et al., 1996), 50-100 nм toxin concentration produced saturating blockade of the P-type Ca current. At concentrations $<100 \mathrm{~nm}$, the toxin had no effect on identified subthalamic T-, L-, and N-type Ca current. These data are consistent with occlusion studies, performed in other neuronal types, which demonstrated a high selectivity of the toxin when used in the nanomolar range (Brown et al., 1994; Foehring and Scroggs, 1994; Fisher and Bourque, 1995; Desmadryl et al., 1997; Churchill and Macvicar, 1998; Connor and Christie, 1998).

The toxin $\omega$-Aga-IVA retained a high degree of selectivity when used in the micromolar range. It had no effect on voltage-gated $\mathrm{Na}$ and $\mathrm{K}$ channels and on L- and T-type Ca channels. However, its selectivity was not complete, as demonstrated by its significant reduction of $\omega$-CgTX-sensitive $\mathrm{N}$-type $\mathrm{Ca}$ channel currents.

The block of N-type Ca channel current by $1 \mu \mathrm{M} \omega$-Aga-IVA was readily assessed in sympathetic neurons, in which up to $90 \%$ of the $\mathrm{Ca}$ current flows through $\omega$-CgTX-sensitive N-type Ca channels (Boland et al., 1994). In subthalamic neurons, the sensitivity of $\mathrm{N}$-type $\mathrm{Ca}$ channels to $\omega$-Aga-IVA was inferred from the partial occlusion between $\omega$-Aga-IVA $(1 \mu \mathrm{M})$ and $\omega$-CgTX $(2.5 \mu \mathrm{M})$ blocking effects. A similar overlap in the current components targeted by $1 \mu \mathrm{M} \omega$-Aga-IVA and $\omega$-CgTX has been documented in other neuronal types (Yu and Shinnick-Gallagher, 1997), suggesting that other mammalian central neurons may express $\mathrm{N}$-type Ca channels that are weakly sensitive to $\omega$-Aga-IVA.

Another high-threshold Ca current was also targeted by $\omega$-AgaIVA $(1 \mu \mathrm{M})$ in subthalamic neurons. The current that remained in the presence of $\omega$-CgTX, nimodipine, and 100-200 nM $\omega$-AgaIVA, a combination of antagonists designed to selectively inhibit $\mathrm{N}-$, L-, and P-type Ca channels, was partially blocked by an increase in $\omega$-Aga-IVA concentration from $100 \mathrm{~nm}$ to $1 \mu \mathrm{M}$. In contrast to the transient Q-type Ca current described in some neurons (Randall and Tsien, 1995; Desmadryl et al., 1997; Mermelstein et al., 1999), it resembled the $\omega$-Aga-IVA-sensitive P-type $\mathrm{Ca}$ current in its activation and inactivation properties.

\section{Voltage-dependent unblock suggests a common mechanism of block}

Previous studies in Purkinje neurons have demonstrated that $\omega$-Aga-IVA is a channel-gating modifier that shows striking voltage dependence in its affinity for P-type $\mathrm{Ca}$ channels (McDonough et al., 1997b). Our data indicate that a similar mechanism is engaged by the high-affinity blockade of subthalamic neuron P-type $\mathrm{Ca}$ channels. In these cells as in Purkinje neurons, trains of large depolarizations completely recovered the current blocked by $50-$ $100 \mathrm{~nm} \omega$-Aga-IVA. Consistent with a complete unbinding of the toxin, current reblock occurred after termination of the large depolarizations with a time course identical to that seen during the first exposure to the toxin.

For practical reasons, we investigated the N-type Ca current block by $\omega$-Aga-IVA in sympathetic neurons. With protocols adapted to minimize current inactivation, voltage-dependent relief of N-type Ca current block was evident. However, it was quantitatively different from the relief of the P-type current block in subthalamic and Purkinje neurons, because it was less complete and kinetically more complex. Current reblock, after termination of the large depolarizations, showed a multiexponential time course. It was too rapid to represent the toxin binding to the channels, suggesting a relatively stable association of $\omega$-Aga-IVA to unblocked channels.

Although it is likely, we were unable to demonstrate the voltage- dependent unblock of the additional current component affected by $1 \mu \mathrm{M} \omega$-Aga-IVA. This current fraction was too small, and current reblock in the presence of $1 \mu \mathrm{M}$ toxin was too fast to allow a precise measurement of the current amplitude after trains of large depolarizations. Still, our data on $\mathrm{P}$ - and $\mathrm{N}$-type $\mathrm{Ca}$ channel currents are consistent with a general mechanism for $\omega$-Aga-IVA action as a gating modifier, whose binding to low- or high-affinity sites likely interferes with the voltage sensors of these channels.

\section{Structural correlates of $\omega$-Aga-IVA-sensitive Ca channels}

Gating modifiers of voltage-gated ion channels recognize common features in the extracellular S3-S4 linker that flanks the channel S4 transmembrane voltage sensor (Li-Smerin and Swartz, 1998). In the case of the $\alpha 1 \mathrm{~A}$ subunit, a high-affinity binding site for $\omega$-AgaIVA has been located to the S3-S4 linker of domain IV (Bourinet et al., 1999). Alternate splicing in this region produces two isoforms, $\alpha 1 \mathrm{~A}-\mathrm{a}$ and $\alpha 1 \mathrm{~A}-\mathrm{b}$, which differ by the insertion of two amino acids (NP) in positions 1605 and 1606. These splice variants show respectively high and low affinity for $\omega$-Aga-IVA, and they may account for the native $\mathrm{P}$ - and Q-type $\mathrm{Ca}$ currents recorded in mammalian central neurons.

\section{P-type Ca channels}

Our data demonstrate that P-type Ca channels in subthalamic and cerebellar Purkinje neurons are very similar to the $\omega$-Aga-IVAsensitive G1 Ca channels that have been extensively characterized in cerebellar granule cells (Tottene et al., 1996). They displayed the same kinetics during test depolarization and the same dramatic steady state inactivation ( $\mathrm{V}_{1 / 2}$, approximately $\left.-65 \mathrm{mV}\right)$. These channels are not identical though. Subthalamic P-type Ca channels and cerebellar G1 Ca channels did activate with comparable voltage dependence (both currents carried by $5 \mathrm{~mm} \mathrm{Ba}^{2+}$ peaked at approximately $-10 \mathrm{mV}$ ). However, the P-type $\mathrm{Ca}$ channels in Purkinje neurons showed their typical more negative range for activation (Regan, 1991), with a peak of the $I-V$ curve located at approximately $-25 \mathrm{mV}$.

Altogether, these findings are consistent with the hypothesis that neuronal P-type $\mathrm{Ca}$ channels, defined by their sensitivity to nanomolar amounts of the toxin $\omega$-Aga-IVA, belong to the same class A gene family. They may display minor structural differences, but their $\alpha 1$ subunits are likely to be very similar to the splice variant $\alpha 1 \mathrm{~A}-\mathrm{a}$, the only $\alpha 1 \mathrm{~A}$ isoform identified so far that carries a highaffinity binding site for $\omega$-Aga-IVA (Bourinet et al., 1999).

\section{N-type Ca channels}

$\mathrm{N}$ - and P-type $\mathrm{Ca}$ channels are closely related, with extensive homology between their respective $\alpha 1 \mathrm{~B}$ and $\alpha 1 \mathrm{~A}$ subunits (Tsien et al., 1995). They share high-affinity binding sites to the $\mathrm{Ca}$ channel antagonists $\omega$-conotoxin-MVIIC and grammatoxin (McDonough et al., 1996, 1997a). They display similar gating properties, and, except for their different sensitivity to selective blockers, they are nearly indistinguishable (Plummer et al., 1989; Usowicz et al., 1992; Rittenhouse and Hess, 1994; Dove et al., 1998). It is thus not surprising that $\mathrm{N}$-type $\mathrm{Ca}$ channels showed weak sensitivity to the P-type Ca channel blocker $\omega$-Aga-IVA.

In sympathetic neurons, we observed a partial blockade $(\sim 30 \%)$ of the N-type current after exposure to $\omega$-Aga-IVA at micromolar concentrations, suggesting that a large fraction of the $\omega$-CgTXsensitive N-type Ca current is insensitive to $\omega$-Aga-IVA. Such heterogeneity is consistent with the diversity of the $\alpha 1 \mathrm{~B}$ subunits that is generated by differential splicing in these cells (Lin et al., 1997; Lü and Dunlap, 1999). Interestingly, some variants differ in the S3-S4 linkers of domains III and IV, which are possible binding sites for $\omega$-Aga-IVA (Lin et al., 1997). It will be interesting to see whether $\omega$-Aga-IVA discriminates between these different $\mathrm{N}$-type Ca channel subtypes.

In subthalamic neurons, approximately the same $30 \%$ fraction of the $\omega$-CgTX-sensitive Ca current was blocked by $\omega$-Aga-IVA. We do not know whether this partial block represents incomplete or 
maximal effect of $\omega$-Aga-IVA, because we did not perform occlusion experiments with toxin concentrations greater than $1 \mu \mathrm{M}$.

\section{Q-type and other high-threshold Ca channels}

In the absence of structural data, weak sensitivity to the toxin $\omega$-Aga-IVA $(1 \mu \mathrm{M})$ has been the main criterion to define Q-type $\mathrm{Ca}$ channels (Sather et al., 1994, Randall and Tsien, 1995). These channels, whose structural identity was recently established (Bourinet et al., 1999), have been challenging objects of study.

Unlike L-, N-, and P-type Ca channels whose investigation is greatly facilitated by their predominant expression in some excitable cells, Q-type Ca channels account for a relatively small component of the whole-cell Ca current recorded in cerebellar granule cells (Randall and Tsien, 1995). Because these cells express a significant P-type Ca current, the pharmacological separation of the two current components is difficult. Despite the widespread expression of $\alpha 1 \mathrm{~A}$ genes in mammalian CNS (Westenbroek et al., 1995; Sakurai et al., 1996), so far, no favorable experimental system has been identified for studies of native Q-type $\alpha 1 \mathrm{~A}$ Ca channels.

Our finding that more than one $\mathrm{Ca}$ channel type show weak but significant sensitivity to $1 \mu \mathrm{M} \omega$-Aga-IVA underlies the difficulty in relating the current blocked by $1 \mu \mathrm{M} \omega$-Aga-IVA to $\alpha 1 \mathrm{~A}$ Q-type $\mathrm{Ca}$ channels. This composite current is carried through $\omega$-CgTXsensitive $\alpha 1 \mathrm{~B} \mathrm{~N}$-type $\mathrm{Ca}$ channels and other $\mathrm{Ca}$ channel types, which may include $\alpha 1 \mathrm{~A}$ Q-type $\mathrm{Ca}$ channels and possibly $\alpha 1 \mathrm{E}$ $\mathrm{R}$-type Ca channels. The latter are expressed in subthalamic neurons (Yokoyama et al., 1995), and their pharmacology in expression systems suggest that some (Soong et al., 1993; Stephens et al., 1997), but not all (Ellinor et al., 1993; Wakamori et al., 1994), are blocked by $1 \mu \mathrm{M} \omega$-Aga-IVA. Considering the high degree of homology of DHP-insensitive Ca channels, it is likely that $\omega$-AgaIVA $(1 \mu \mathrm{M})$ targets variants in each class of this family. Weak sensitivity to $\omega$-Aga-IVA and gating properties (which are highly variable depending on the $\beta$ subunit associated with the $\alpha 1 \mathrm{~A}$ subunit) are thus incomplete criteria of identification for $\alpha 1 \mathrm{~A}$ Q-type Ca channels. The full characterization of these channels in neurons will require a combined approach with molecular, pharmacological, and electrophysiological tools, as already begun in cortical and neostriatal neurons (Mermelstein et al., 1999).

The toxin $\omega$-Aga-IVA retains its usefulness as a selective and potent blocker of neuronal P-type Ca channels. It is not a selective blocker of $\alpha 1 \mathrm{~A} \mathrm{Ca}$ channels because, like many other Ca channel antagonists (Hillyard et al., 1992; McDonough et al., 1996, 1997a), it affects a variety of DHP-insensitive $\mathrm{Ca}$ channels when used in the micromolar range. Notwithstanding this limitation, it will continue to be an important tool to relate the properties of $\mathrm{Ca}$ channel clones to the complexity of their native counterparts.

\section{REFERENCES}

Adams ME, Myers RA, Imperial JS, Olivera BM (1993) Toxityping rat brain calcium channels with $\omega$-toxins from spider and cone snail venoms. Biochemistry 32:12566-12570.

Bargas J, Howe A, Eberwine J, Cao Y, Surmeier DJ (1994) Cellular and molecular characterization of $\mathrm{Ca}^{2+}$ currents in acutely isolated, adult rat neostriatal neurons. J Neurosci 11:6667-6686.

Bergman H, Wichmann T, DeLong MR (1990) Reversal of experimental parkinsonism by lesions of the subthalamic nucleus. Science 249:1436-1438.

Berrow NS, Brice NL, Tedder I, Page KM, Dolphin AC (1996) Properties of cloned rat $\alpha 1 \mathrm{~A}$ calcium channels transiently expressed in the COS-7 cell line. Eur J Neurosci 9:739-748.

Boland LM, Morrill JA, Bean BP (1994) $\omega$-Conotoxin block of N-type calcium channels in frog and rat sympathetic neurons. J Neurosci 14:5011-5027.

Bourinet E, Soong TW, Sutton K, Slaymaker S, Mathews E, Monteil A, Zamponi GW, Nargeot J, Snutch TP (1999) Splicing of $\alpha 1 \mathrm{~A}$ subunit gene generates phenotypic variants of P- and Q-type calcium channels. Nat Neurosci 2:407-415.

Brown AM, Sayer RJ, Schwindt PC, Crill WE (1994) P-type calcium channels in rat neocortical neurones. J Physiol (Lond) 475.2:197-205.

Catterall WA (1980) Neurotoxins that act on voltage-sensitive sodium channels in excitable membranes. Annu Rev Pharmacol Toxicol 20:15-43.

Churchill D, Macvicar BA (1998) Biophysical and pharmacological char- acterization of voltage-dependent $\mathrm{Ca}^{2+}$ channels in neurons isolated from rat nucleus accumbens. J Neurophysiol 79:635-647.

Connor M, Christie MJ (1998) Modulation of $\mathrm{Ca}^{2+}$ channel currents of acutely dissociated rat periaqueductal grey neurons. J Physiol (Lond) 509:47-58.

Cox DH, Dunlap K (1992) Pharmacological discrimination of N-type from L-type calcium current and its selective modulation by transmitters. J Neurosci 12:906-914.

Desmadryl G, Chambard J-M, Valmier J, Sans A (1997) Multiple voltagedependent calcium currents in acutely isolated mouse vestibular neurons. Neuroscience 78:511-522.

Dove LS, Abbott LC, Griffith WH (1998) Whole-cell and single-channel analysis of P-type calcium currents in cerebellar Purkinje cells of leaner mutant mice. J Neurosci 18:7687-7699.

Dunlap K, Luebke JI, Turner TJ (1995) Exocytotic $\mathrm{Ca}^{2+}$ channels in mammalian central neurons. Trends Neurosci 18:89-98.

Eliot LS, Johnston D (1994) Multiple components of calcium current in acutely dissociated dentate gyrus granule neurons. J Neurophysiol $72: 762-777$

Ellinor PT, Z hang JF, Randall AD, Zhou M, Schwarz TL, Tsien RW, Horne WA (1993) Functional expression of a rapidly inactivating neuronal calcium channel. Nature 363:455-458.

Elmslie KS (1997) Identification of the single channels that underlie the $\mathrm{N}$-type and L-type calcium currents in bullfrog sympathetic neurons. J Neurosci 17:2658-2668.

Fisher TE, Bourque CW (1995) Voltage-gated calcium currents in the magnocellular neurosecretory cells of the rat supraoptic nucleus. J Physiol (Lond) 486:571-580.

Foehring RC, Scroggs RS (1994) Multiple high-threshold calcium currents in acutely isolated rat amygdaloid pyramidal cells. J Neurophysiol 71:433-436.

Forti L, Tottene A, Moretti A, Pietrobon D (1994) Three novel types of voltage-dependent calcium channels in rat cerebellar neurons. J Neurosci 14:5243-5258.

Fox AP, Nowycky MC, Tsien RW (1987) Kinetic and pharmacological properties distinguishing three types of calcium currents in chick sensory neurones. J Physiol (Lond) 394:149-172.

Fujita Y, Mynlieff M, Dirksen RT, Kim MS, Niidome T, Nakai J, Friedrich T, Iwabe N, Miyata T, Furuichi, T, Furutama D, Mikoshiba K, Mori Y, Beam KG (1993) Primary structure and functional expression of the $\omega$-conotoxin-sensitive $\mathrm{N}$-type calcium channel from rabbit brain. Neuron 10:585-598.

Hammond C, Yelnik J (1983) Intracellular labelling of rat subthalamic neurones with horseradish peroxidase: computer analysis of dendrites and characterization of axon arborization. Neuroscience 8:781-790.

Herrington J, Bookman RJ (1994) Pulse control V3.0: Igor XOPs for patch-clamp data acquisition. Miami: University of Miami.

Hillyard DR, Monje VD, Mintz IM, Bean BP, Nadasdi L, Ramachandran J, Miljanich G, Azimi-Zoonooz A, McIntosh JM, Cruz LJ, Imperial JS, Olivera BM (1992) A new Conus peptide ligand for mammalian presynaptic $\mathrm{Ca}^{2+}$ channels. Neuron 9:69-77.

Iribe Y, Moore K, Pang KC, Tepper JM (1999) Subthalamic stimulationinduced synaptic responses in substantia nigra pars compacta dopaminergic neurons in vitro. J Neurophysiol 82:925-933.

Lin Z, Haus S, Edgerton J, Lipscombe D (1997) Identification of functionally distinct isoforms of the N-type $\mathrm{Ca}^{2+}$ channel in rat sympathetic ganglia and brain. Neuron 18:153-166.

Li-Smerin Y, Swartz KJ (1998) Gating modifier toxins reveal a conserved structural motif in voltage-gated $\mathrm{Ca}^{2+}$ and $\mathrm{K}^{+}$channels. Proc Natl Acad Sci USA 95:8585-8589.

Llinas R, Sugimori M, Lin JW, Cherksey B (1989) Blocking and isolation of a calcium channel from neurons in mammals and cephalopods utilizing a toxin fraction (FTX) from funnel-web spider poison. Proc Natl Acad Sci USA 86:1689-1693.

Lorenzon NM, Foehring RC (1995) Characterization of pharmacologically identified voltage-gated calcium channel currents in acutely isolated rat neocortical neurons. J Neurophysiol 73:1430-1442.

Lü Q, Dunlap K (1999) Cloning and functional expression of novel $\mathrm{N}$-type $\mathrm{Ca}^{2+}$ channel variants. J Biol Chem 274:34566-34575.

McCleskey EW, Fox AP, Feldman DH, Cruz LJ, Olivera BM, Tsien RW, Yoshikami D (1987) Omega-conotoxin: direct and persistent blockade of specific types of calcium channels in neurons but not muscle. Proc Natl Acad Sci USA 84:4327-4331.

McDonough SI, Swartz KJ, Mintz IM, Boland LM, Bean BP (1996) Inhibition of calcium channels in rat central and peripheral neurons by $\omega$-conotoxin-M V IIC. J Neurosci 16:2612-2623.

McDonough SI, Lampe RA, Keith RA, Bean BP (1997a) Voltagedependent inhibition of $\mathrm{N}$ - and P-type calcium channels by the peptide toxin $\omega$-grammotoxin-SIA. Mol Pharmacol 52:1095-1104.

McDonough SI, Mintz IM, Bean BP (1997b) Alteration of P-type calcium channel gating by the spider toxin $\omega$-Aga-IVA. Biophys J 72:2117-2128.

Mermelstein PG, Foehring RC, Tkatch T, Song W-J, Baranauskas G, Surmeier DJ (1999) Properties of Q-Type calcium channels in neostriatal and cortical neurons are correlated with $\beta$ subunit expression. J Neurosci 19:7268-7277.

Mikami A, Imoto K, Tanabe T, Niidome T, Mori Y, Takeshima H, Narumiya S, Numa S (1989) Primary structure and functional expres- 
sion of the cardiac dihydropyridine-sensitive calcium channel. Nature 340:230-233.

Mintz IM, Adams ME, Bean BP (1992) P-type calcium channels in rat central and peripheral neurons. Neuron 9:85-95.

Moreno H, Rudy B, Llinas R (1997) $\beta$ subunits influence the biophysical and pharmacological differences between P-and Q-type calcium currents expressed in a mammalian cell line. Proc Natl Acad Sci USA 94:14042-14047.

Mori Y, Friedrich T, Kim MS, Mikami A, Nakai J, Ruth P, Bosse E, Hofmann F, Flockerzi V, Furuichi T, Mikoshiba K, Imoto K, Tanabe T, Numa S (1991) Primary structure and functional expression from complementary DNA of a brain calcium channel. Nature 350:398-402.

Newcomb R, Szoke B, Palma A, Wang G, Chen Xh, Hopkins W, Cong R, Miller J, Urge L, Tarczy-Hornoch K, Loo JA, Dooley DJ, Nadasdi L, Tsien RW, Lemos J, Miljanich G (1998) Selective peptide antagonist of the class E calcium channel from the venom of the tarantula Hysterocrates gigas. Biochemistry 37:15353-15362.

Niidome T, Teramoto T, Murata Y, Tanaka I, Seto T, Sawada K, Mori Y Katayama K (1994) Stable expression of the neuronal BI (class A) calcium channel in baby hamster kidney cells. Biochem Biophys Res Commun 203:1821-1827.

Nowycky MC, Fox AP, Tsien RW (1985) Three types of neuronal calcium channel with different calcium agonist sensitivity. Nature 316:440-443.

Olivera BM, Gray WR, Zeikus R, McIntosh JM, Varga J, Rivier J, de Santos V, Cruz LJ (1985) Peptide neurotoxins from fish-hunting cone snails. Science 230:1338-1343.

Plummer MR, Logothetis DE, Hess P (1989) Elementary properties and pharmacological sensitivities of calcium channels in mammalian peripheral neurons. Neuron 2:1453-1463.

Randall A, Tsien RW (1995) Pharmacological dissection of multiple types of $\mathrm{Ca}^{2+}$ channel currents in rat cerebellar granule neurons. J Neurosci 15:2995-3012.

Regan LJ (1991) Voltage-dependent calcium currents in Purkinje cells from rat cerebellar vermis. J Neurosci 11:2259-2269.

Regan LJ, Sah DW, Bean BP (1991) $\mathrm{Ca}^{2+}$ channels in rat central and peripheral neurons: high-threshold current resistant to dihydropyridine blockers and omega-conotoxin. Neuron 6:269-280.

Rehm H, Tempel BL (1991) Voltage-gated $\mathrm{K}^{+}$channels of the mammalian brain. FASEB J 5:164-170.

Rittenhouse AR, Hess P (1994) Microscopic heterogeneity in unitary N-type calcium currents in rat sympathetic neurons. J Physiol (Lond) 474:87-99.

Sakurai T, Westenbroek RE, Rettig J, Hell J, Catterall WA (1996) Biochemical properties and subcellular distribution of the BI and rbA isoforms of alpha $1 \mathrm{~A}$ subunits of brain calcium channels. J Cell Biol 134:511-528.

Sather WA, Tanabe T, Zhang JF, Mori Y, Adams ME, Tsien RW (1993)
Distinctive biophysical and pharmacological properties of class A (BI) calcium channel alpha 1 subunits. Neuron 11:291-303.

Sather WA, Tanabe T, Zhang JF, Tsien RW (1994) Biophysical and pharmacological characterization of a class A calcium channel. Ann NY Acad Sci 747:294-301.

Soong TW, Stea A, Hodson CD, Dubel SJ, Vincent SR, Snutch TP (1993) Structure and functional expression of a member of the low voltageactivated calcium channel family. Science 260:1133-1136.

Stea A, Tomlinson WJ, Soong TW, Bourinet E, Dubel SJ, Vincent SR, Snutch TP (1994) Localization and functional properties of a rat brain alpha $1 \mathrm{~A}$ calcium channel reflect similarities to neuronal Q- and P-type channels. Proc Natl Acad Sci USA 91:10576-10580.

Stephens GJ, Page KM, Burley JR, Berrow NS, Dolphin AC (1997) Functional expression of rat brain cloned $\alpha 1 \mathrm{E}$ calcium channels in COS-7 cells. Pflugers Arch 433:523-532.

Tottene A, Moretti A, Pietrobon D (1996) Functional diversity of P-type and R-type calcium channels in rat cerebellar neurons. J Neurosci 16:6353-6363.

Tsien RW, Lipscombe D, Madison D, Bley K, Fox A (1995) Reflections on $\mathrm{Ca}^{2+}$-channel diversity, 1988-1994. Trends Neurosci 18:52-54.

Usowicz MM, Sugimori M, Cherksey B, Llinas R (1992) P-type calcium channels in the somata and dendrites of adult cerebellar Purkinje cells. Neuron 9:1185-1199.

Wakamori M, Niidome T, Furutama D, Furuichi T, Mikoshiba K, Fujita Y, Tanaka I, Katayama K, Yatani A, Schwartz A, Mori Y (1994) Distinctive functional properties of the neuronal BII (class E) calcium channel. Receptors Channels 2:303-314.

Westenbroek RE, Sakurai T, Elliott EM, Hell JW, Starr TV, Snutch TP, Catterall WA (1995) Immunochemical identification and subcellular distribution of the $\alpha 1 \mathrm{~A}$ subunits of brain calcium channels. J Neurosci 15:6403-6418

Williams ME, Brust PF, Feldman DH, Patthi S, Simerson S, Maroufi A, McCue AF, Velicelebi G, Ellis SB, Harpold MM (1992a) Structure and functional expression of an $\omega$-conotoxin-sensitive human $\mathrm{N}$-type calcium channel. Science 257:389-395.

Williams ME, Feldman DH, McCue AF, Brenner R, Velicelebi G, Ellis SB, Harpold MM (1992b) Structure and functional expression of alpha 1, alpha 2 , and beta subunits of a novel human neuronal calcium channel subtype. Neuron 8:71-84.

Yokoyama CT, Westenbroek RE, Hell JW, Soong TW, Snutch TP, Catterall WA (1995) Biochemical properties and subcellular distribution of the neuronal class $\mathrm{E}$ calcium channel alpha 1 subunit. J Neurosci 15:6419-6432.

Yu B, Shinnick-Gallagher P (1997) Dihydropyridine- and neurotoxinsensitive and -insensitive calcium currents in acutely dissociated neurons of the rat central amygdala. J Neurophysiol 77:690-701. 